\title{
Mercimekte (Lens culinaris M.) Hızlı Islah Teknikleri Kullanılarak Generasyon Süresinin Kısaltılması
}

\author{
Gözde ÇELIK ÖZER*®, Cuma KARAOĞLU®, Abdulkadir AYDOĞAN@, \\ Havva Vildan KILINÇ(D) \\ *Tarla Bitkileri Merkez Araștırma Enstitüsü, Ankara, Türkiye \\ Sorumlu yazar e-posta (Corresponding author e-mail): gozde.celik@tarimorman.gov.tr \\ Geliș Tarihi (Received): 26.11.2019＜noBreak>Kabul Tarihi (Accepted): 11.12.2019
}

\begin{abstract}
Öz
Bu çalıșma 2019 yılında; Tarla Bitkileri Merkez Araștırma Enstitüsü Müdürlüğü Baklagil Islah Birimi ve Biyoteknoloji Araștırma Merkezi ișbirliği ile yürütülmüștür. Mercimekte yabancı ot sorununa çözüm bulmak için dayanıklıı̆ı tespit edilmiș hatlar ile ülkemizde en fazla ekimi yapılan kıșlık mercimek çeșitleri resiprokal olarak melezlenmiștir. Bu çalıșmanın amacı, melezlenen popülasyonlarda genetik ilerlemeyi arttırmak için kontrollü koșullarda mercimeğin günlük ıșığa maruz kalma süresini ve ıșıklanma yoğunluğunu yükselterek generasyonlar arası süreyi kısaltmaktır. Arazi koșullarındaki klasik mercimek ıslah çalıșmaları sonucunda bir yılda bir generasyon ilerleme sağlanabilmektedir. Bu çalıșmada bitkilerin hem günlük ıșığa maruz kalma süresinin uzatılması hem de erken tohum hasadı gerçekleștirilmesi suretiyle populasyonlar 60 gün içerisinde bir generasyon ilerletilmiștir. Sera ve iklim odasında ıșıklandırma yoğunluğu ve süresi farklı tutularak bitkilerdeki morfolojik ve fizyolojik değișimler gözlemlenmiștir. Çalışma ile mercimekte hızlı ıslah teknikleri kullanımaya bașlanmıștır. Bu tekniklerin klasik ıslah çalıșmalarına entegre edilmesi ile daha kısa sürede istenilen özellikte mercimek çeșitleri geliștirilecektir.
\end{abstract}

Anahtar Kelimeler: Hızıı ıslah, mercimek, melezleme, fotoperiyot, generasyon

\section{The Use of Speed Breeding Techniques to Shorten Generation Cycle in Lentil (Lens culinaris M.)}

\section{Abstract}

This research was conducted to find a solution to weed problem in lentil cultivation. Known as herbicide tolerant lines and commonly cultivated winter lentil varieties in Turkey were hybridized reciprocally. The aim of this study was to shorten time between lentil generations by increasing light exposure period and luminescence intensity under controlled conditions to increase genetic progress of hybrid populations. One generation progress can be achieved in a year by conventional lentil breeding studies in field conditions. In this study, by prolonging the light exposure time and early seed harvesting, the populations were progressed one generation within 60 days. Morphological and physiological changes in plants were observed by keeping lighting intensity and duration different in greenhouse and controlled growth room. In this study, speed breeding techniques were used in lentils. By integrating these techniques into classical breeding studies, lentil varieties with the desired characteristics will be developed in a shorter period of time.

Keywords: Speed breeding, lentil, hybridization, photoperiod, generation

\section{Giriș}

Ülkemiz, mercimek çeșitlerinin doğal gen merkezi olarak kabul edilmektedir (Köse, Bozoğlu, \& Mut, 2017). Günümüzde kültürü yapılan mercimeğin (Lens culinaris Medik) gen merkezi Filistin, Suriye ve Türkiye'nin içinde bulunduğu alandır (Cubero, 1984). Mercimek (Lens), baklagiller (Leguminosae) takımının kelebek çiçekliler (Papilionatae) familyasına bağlı Vicieae oymağına mensup beș önemli cinsten (Vicia L., Lathyrus L., Pisum L., Cicer L. ve Lens Miller) birisidir.

Türkiye dünya mercimek üretiminin yaklașık \%7'sini karșılamaktadır. Ülkemizde mercimek üretimi; yıllara göre değişmekle beraber, 
en fazla üretilen baklagil türleri arasında -ikinci sırada yer almaktadır. Mercimek ekim alanlarının yaklașık \%90'ını kırmızı mercimek olușturmaktadır. Mercimek üretimimizin \%6.7'sini olușturan yeșil mercimek, genellikle Orta Anadolu ve Geçit Bölgeleri'nde yetiștirilmektedir (TÜIK, 2018).

Bitkisel kaynaklı ürünler içinde baklagil bitkileri diğer bitkilere göre daha yüksek protein değerlerine sahiptir. Yemeklik baklagiller içerisinde düșük sıcaklığa ve kurağa en dayanıklı bitki mercimektir. Mercimek kıșın bașında ekilip, yaz bașında hasat edildiği için, yaz bașında ikinci bir ürünün yetișmesine de imkan vermektedir (Zulkadir ve ark., 2015).

Bitkisel üretim artıșında en temel unsurların bașında bitki ıslahı gelmektedir. Doğal bitki örtüsünün bugünkü dünya nüfusunun ancak \%5'ini besleyebileceği uzmanlarca ileri sürülmekte olup, bitki genetiği ve ıslahı bilim dalında bugüne kadar gerçekleștirilen gelișmeler ve elde edilen bașarılar tahminlerin de ötesinde olmuștur. Mercimek yetiștirilen alanlarda verim kısıtlayan en önemlifaktörlerden biri yabancı ot sorunudur. Mercimeğin verim kaybı yabancı ot yoğunluğuna bağlı olarak değișebilmektedir (Bukun \& Guler, 2005). Halila (1994), yabancı otların mercimekte \%60-100 oranında verim kaybına yol açtığını ifade etmiştir.

Mercimeğin Orta Anadolu Bölgesi'nde kıșlık olarak yetiștirilememesindeki en büyük neden yabancı ot sorunudur (Thonke, 1991). Mercimek gelișme kabiliyeti zayıf olduğundan yabancı otlar ile rekabete girememekte ve yüksek verim kayıpları olușmaktadır. Mercimeğin zayıf yapısı, herbisitlere olan düșük toleransı ve ruhsatlı herbisit sayısının az olması nedeniyle yabancı ot kontrolünü sağlamak zorlașmaktadır (Ball, Ogg, \& Chevalier,1997). Imi grubu herbisitlere toleranslılığın genetiği konusunda birçok bitkide yapılan çalıșmada toleranslılığın tek bir dominant gen tarafından kontrol edildiği ortaya çıkmıștır (Tan ve ark., 2005).

Nüfus artıșı ve değișen çevre koșulları yetersiz mahsul üretimine sebebiyet vermekte talebi karșılayamamaktadır. Bu da küresel gıda yeterliliği/güvenliği açısından kaygı uyandırmaktadır. Genel olarak bazı temel ürünlerin generasyon dönemlerinin uzun olması nüfus artıșıla birlikte yetersiz mahsul üretimine sebebiyet vermektedir (Ray ve ark., 2013). Birçok ürün grubunda yeni bir çeşit geliştirmek uzun yıllar almaktadır. Klasik ıslah yöntemlerinden olan melezleme ıslahında Islah süresi çok uzundur ve bu süre 11-14 yıl arasında değişmektedir (Panchangam ve ark., 2014; Singh ve ark., 1983).

Son yıllarda geleneksel ıslah metotları ile biyoteknoloji alanındaki çalışmaların (doku kültürü, moleküler çalıșmalar) birbirine entegre edilmesi ile bitki ıslahında önemli gelișmeler elde edilmiștir. Özellikle anter kültürü tekniğininin bitki ıslahında kullanımı ile klasik Islahtaki uzun ișlemler yerine çok daha kısa sürede homozigot bitkiler elde edilmekte ve yeni bir çeșidin ortaya çıkıșında en az 3-4 yıl kazandırmaktadır (Singh ve ark., 1983). Bitki rejenerasyonu için olușturulan protokollerin hızlı ve kolay uygulanabilirliğindeki güçlükler, baklagillerin yapısı ve tekrarlama eksikliği nedeniyle baklagillerde biyoteknolojik (doku kültürü) çalıșmalar çok yavaș ilerlemektedir (Croser, 2002). Baklagillerde doku kültürü tekniklerinin bașarılı bir șekilde uygulandığı, faydalanılabilinir ve sürdürülebilir protokoller henüz bulunmamaktadır (Grewal ve ark., 2009).

Klasik ıslah çalıșmaları ile yeni mercimek çeșitlerin geliștirilmesi uzun yıllar gerektirmekle beraber çok fazla zamana ve emeğe intiyaç duyulmaktadır. Klasik ıslah yöntemleriyle genetik safiyetin sağlanması için en az 6-7 generasyon geçmesi gerekmektedir. Bu süre sonrasında istenilen özellikteki saf hatlar bazen elde edilememekte ve böyle durumlarda uzun süren ıslah programları bașarılı olamamaktadır. Bu nedenle ıslah çalıșmalarında süreyi kısaltmak ve ıslah programlarının etkinliğini arttırmak için yeni teknolojilere bașvurulmaktadır. Yeni teknolojilerden biride hızlı ıslah (speed breeding) tekniğidir. Bu teknik ile bitki gelișimini hızlandırmak için uzun süreli fotoperiyotlar kullanılarak generasyon süresi kısaltılmaktadır. Söz konusu metot sayesinde, popülasyonlarda hızlı generasyon ilerlemesi sağlanarak ıslah süresi kısaltılarak yeni çeșitlerin kısa zamanda ortaya çıkması sağlanmaktadır. Hem bitkilerin gün ıșığına maruz kalma süresi uzatılmakta hem de erken tohum hasadıyla tohumdan tohuma hızlı bir șekilde geçiș yaparak uzun gün/nötr gün bitkileri için üretim sürelerini kısaltmak gibi 
sayısız yolla hızıı ıslah gerçekleștirilebilmektedir (Ray ve ark., 2013).

Ghosh ve ark. (2018) bu konuyla ilgili yapmıș oldukları çalıșmada; ekmeklik buğday, makarnalık buğday, arpa, yulaf, çeșitli brassica türleri, nohut, bezelye, kinoa ve yabani bir tür olan ülkemizde yayılıș gösteren Brachypodium distachyon'un hızı ıslahını destekleyen koșulları optimize etmișlerdir. Araștırıcılar; bitkilerin yetiștirilmesinde kullanılan standart bir fotoperiyot kullanmak yerine, yüksek basınçı sodyum lambalar bulunan serada günde 22 saat bitkilere fotoperiyot uygulamıștır. Çalıșmalarında bitkiler ayrıca kontrol olarak normal fotoperiyotta tam kontrollü sera koșullarında 16 saat fotoperiyoda maruz bırakılmıștır. Her iki koșulda da gündüz ve gece sıcaklığı aynı tutulmuștur $\left(23 / 17^{\circ} \mathrm{C}\right) .12$ saat fotoperiyoda maruz bırakılanlara kıyasla 22 saat fotoperiyot uygulananlarda anthesis (tam çiçeklenme dönemi) süresinde genotipe bağlı olarak azalmalar görülmüștür (22 \pm 2 gün (buğday), $64 \pm 8$ gün (arpa), $33 \pm 2$ gün (nohut). Çalışmada, yılda sadece 2-3 nesil buğday, arpa, nohut ve kanola elde edilebilecek doğal fotoperyodlu sera ile yüksek fotoperiyodlu sera karșılaștırıldığında yüksek fotoperiyodlu seranın 1 yılda 4-6 generasyon ilerletme sağladığı ortaya çıkmıștır.

Ghosh ve ark. (2018) yapmıș oldukları çalıșmada nohut ve bezelyenin hızlı ıslahını destekleyen koșulları optimize etmiș, 60 gün içerisinde tohumlarda 1 generasyon ilerletme sağlamıșlardır. Enstitü arazi koșullarında yürütülen mercimek ıslah çalıșmaları sonucunda elde edilen materyallerde 1 yilda 1 generasyon ilerletme sağlanabilmektedir. Bu çalıșma ile; popülasyonlarda genetik ilerlemeyi arttırmak için kontrollü koșullarda mercimeğin günlük ıșığa maruz kalma süresi ve ışıklanma yoğunluğu yükseltilerek generasyonlar arası süre kısaltılmaya çalışılmıştır.

\section{Materyal ve Yöntem}

Araștırma Tarla Bitkileri Merkez Araștırma Enstitüsü Müdürlüğü merkez kampüsünde bulunan tam kontrollü polikarbon serada ve aynı enstitüye bağı Biyoteknoloji Araștırma Merkezinde bulunan tam kontrollü iklim odasında (Digitech- PG42) gerçekleștirilmiștir.
Sera ve iklim odasının ıșık yoğunluğu, ısısı, nemi ve havalandırması otomatik olarak kontrol edilebilmektedir.

Ghosh ve ark. 2018, çalıșmalarında nohutta uyguladıkları hızlı ıslah yöntemi mercimek için modifiye edilerek detayları așağıda verilmiștir.

Mercimekte herbisite dayanıklıı̆ı aktarmak amacıyla bașlatılan melezleme çalıșmaları neticesinde elde edilen ve herbisite dayanıklı olduğu düșünülen 3 adet F1 (F1-1, F2-2, F33) kademesindeki mercimek popülasyonları ve Çiftçi çeşidi araştırma materyali olarak kullanıımıştır.

Tarla Bitkileri Merkez Araștırma Enstitüsü'ne ait İkizce Araştırma Çiftliği'nde ekili materyaller 2019 yılı Temmuz ayında baklalar tam olgunlașmadan araziden hasat edilmiștir. Tam olgunlașmadan hasat edilen baklalar, nem içeriğinin yüksek olması sebebiyle, $32{ }^{\circ} \mathrm{C}$ karanlık etüvde 4-5 gün kurutulmuştur. Nem içerikleri her gün kontrol edilmiștir. Baklalar etüvde kurutulduktan sonra $0,5 \mathrm{ppm}$ giberellik asit $\left(\mathrm{GA}_{3}\right)$ uygulanarak $+4{ }^{\circ} \mathrm{C}$ ' de 4 gün bekletilmiștir. Giberellik asit $\left(\mathrm{GA}_{3}\right)$ uygulamadaki temel amaç dormansiyi kırarak tohumların aynı anda çimlenmesini teșvik etmektir. $\mathrm{GA}_{3}$ uygulanan tohumlar temiz filtre kağıdında $23{ }^{\circ} \mathrm{C}$ karanlık inkübatöre alınmıș 2-3 gün sonra tohumlarda çimlenmeler gözlenmeye bașlanmıștır. Hasat olgunluğuna gelmemiș baklalarda çimlenme problemini ortadan kaldırmak amacıyla bahsedilen ön uygulamalar yapılmaktadır (Ghosh ve ark., 2018).

Ön uygulamadan geçmiş çimlenmiş tohumlar $13 \times 20 \mathrm{~cm}$ ölçülerindeki saksılara tesadüf parsellerinde faktöriyel deneme desenine göre 3 tekerrürlü olarak her saksıda 3 bitki olacak șekilde ekilmiștir. Saksıda yetiștirme ortamı olarak torf (\%75) ve perlit (\%25) karıșımı kullanılmıștır.

\section{Tam Kontrollü Polikarbon Seranın Iklim} Özellikleri

Bitkiler, 16 saat ıșık 8 saat karanlık fotoperiyodunda, $17 / 23 \quad{ }^{\circ} \mathrm{C}$ gece/gündüz sıcaklığında denemenin kurulduğu serada yetiștirilmiștir. Sera koșullarında nem oranı \%70-75 arasında değișmiștir. 


\section{Tam Kontrollü Iklim Odasının İlim Özellikleri}

Bitkiler, 190 bin lüx toplam ıșık, bitki seviyesinde 650 milimol 22 saat ıșı/ $/ 2$ saat karanlık fotoperiyotunda, $17 / 23{ }^{\circ} \mathrm{C}$ gece/ gündüz sıcaklı̆ıında denemenin kurulduğu iklim odasında (Digitech-PG42) yetiștirilmiștir. İklim odasındaki nem oranı \%70-75 arasında değișmiștir.

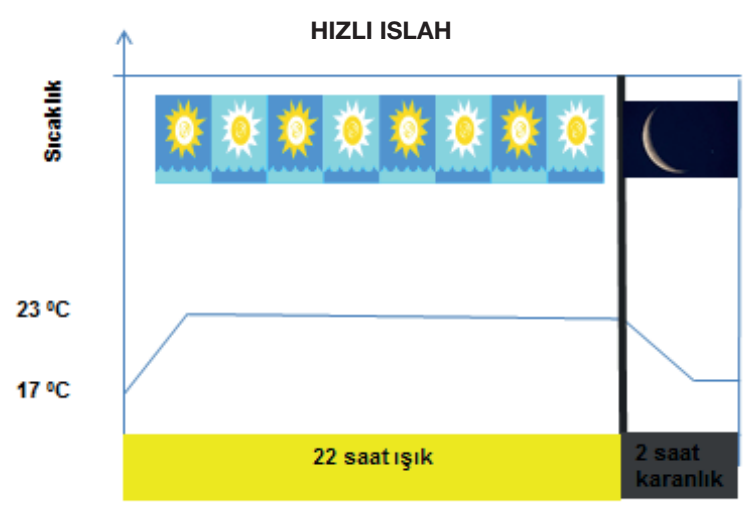

Șekil 1. İklim Odası Șartlarında Fotoperiyod Süresi Figure 1. Photoperiod duration in controlled growth room

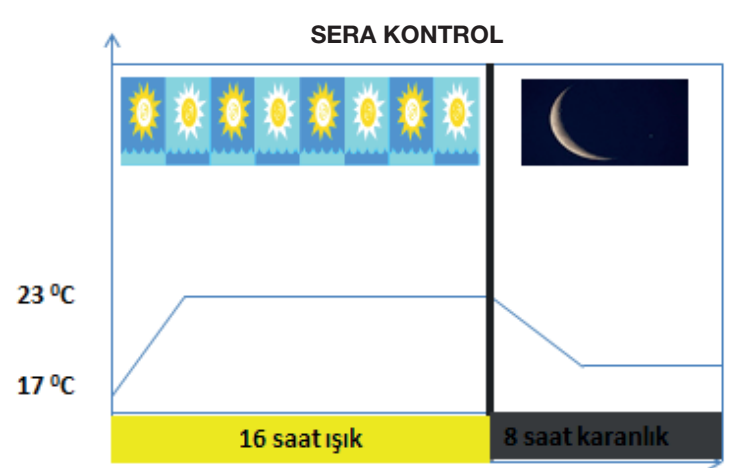

Șekil 2. Sera (kontrol) șartlarında fotoperiyot süresi Figure 2. Photoperiod duration in greenhouse conditions

\section{Bulgular ve Tartıșma}

Așağıdaki değerler araștırmanınyürütüldüğü iklim odası (hızlı ıslah) ve tam kontrollü serada (kontrol) alınan sonuçların ortalaması olarak kaydedilmiștir. Çıkış tarihi, \%50 çiçeklenme gün sayısı, bitki boyu, ilk bakla yüksekliği, olgunlaşma gün sayısı, bitkide bakla sayısı, bitkide tohum sayısı gözlemleri alınmıștır. Alınan gözlem değerlerini içeren Çizelge1 ve 2'de sunulmuștur.

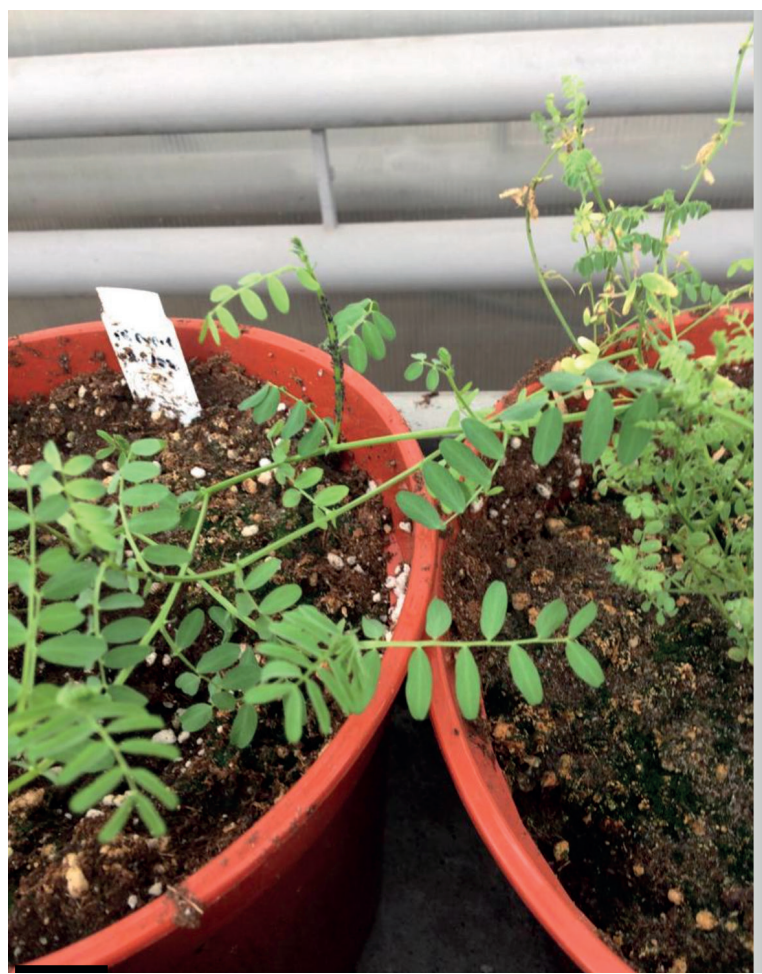

Șekil 3. Ekimden 4 hafta sonra

a) Serada F1-2 populasyonu

Figure 3. 4 weeks after sowing

a) F1-2 Population in greenhouse conditions

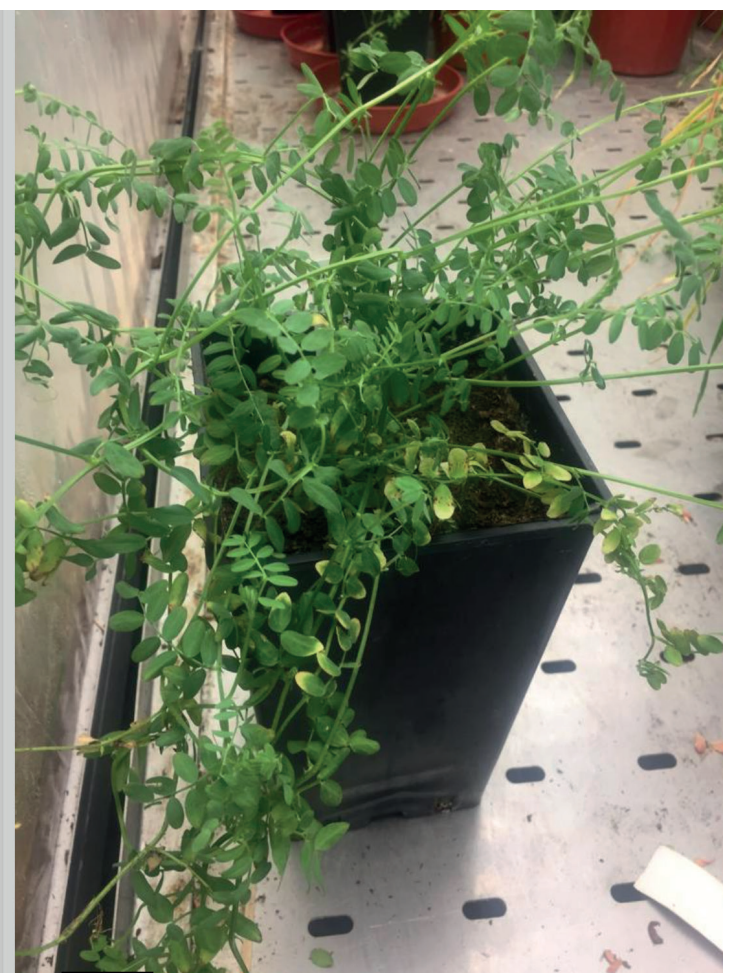

b) İklim odasında F1-2 populasyonu

b) F1-2 Population in controlled growth room 
Çizelge 1. İklim Odası Koșullarında Elde Edilen Gözlem Değerleri

Table 1. Observation values in controlled growth room

\begin{tabular}{|c|c|c|c|c|c|c|c|c|}
\hline \multirow[b]{2}{*}{ Hat/Çeșit } & \multirow{2}{*}{$\begin{array}{l}\text { Ekim } \\
\text { Tarihi }\end{array}$} & \multirow[b]{2}{*}{ Çıkıș Tarihi } & \multirow{2}{*}{$\begin{array}{l}\% 50 \\
\text { Ç.G.S. } \\
\text { (gün) }\end{array}$} & \multirow{2}{*}{$\frac{\mathrm{IBY}}{(\mathrm{cm})}$} & \multirow{2}{*}{$\frac{\text { B.B. }}{(\mathrm{cm})}$} & \multirow{2}{*}{$\frac{\text { O.G.S. }}{\text { (gün) }}$} & \multirow{2}{*}{$\begin{array}{c}\text { Bakla } \\
\begin{array}{c}\text { Sayısı } \\
\text { adet }\end{array}\end{array}$} & \multirow{2}{*}{$\begin{array}{c}\text { Bitkide } \\
\begin{array}{c}\text { Tohum Sayısı } \\
\text { adet }\end{array}\end{array}$} \\
\hline & & & & & & & & \\
\hline F1-1 & 21. Haz & 22. Haz & 30 & 30 & 50 & 60 & 20 & 30 \\
\hline F1-1 & 21. Haz & 23. Haz & 32 & 30 & 57 & 62 & 21 & 31 \\
\hline F1.1 & 21. Haz & 22. Haz & 32 & 30 & 55 & 64 & 22 & 30 \\
\hline F1-2 & 21. Haz & 22. Haz & 34 & 34 & 55 & 64 & 20 & 29 \\
\hline F1-2 & 21. Haz & 22. Haz & 32 & 32 & 53 & 65 & 22 & 28 \\
\hline F1-2 & 21. Haz & 23. Haz & 34 & 35 & 54 & 64 & 24 & 28 \\
\hline F1-3 & 21. Haz & 22. Haz & 33 & 31 & 50 & 67 & 20 & 30 \\
\hline F1-3 & 21. Haz & 23. Haz & 30 & 33 & 52 & 65 & 21 & 28 \\
\hline F1-3 & 21. Haz & 22. Haz & 32 & 34 & 53 & 68 & 20 & 32 \\
\hline Çiftçi & 21. Haz & 22. Haz & 30 & 32 & 50 & 60 & 22 & 30 \\
\hline Çiftçi & 21. Haz & 22. Haz & 32 & 34 & 50 & 60 & 21 & 27 \\
\hline Çiftçi & 21. Haz & 22. Haz & 31 & 33 & 51 & 55 & 20 & 28 \\
\hline Minimum & & & 30 & 30 & 50 & 55 & 20 & 27 \\
\hline Maksimum & & & 34 & 35 & 57 & 68 & 24 & 32 \\
\hline Ortalama & & & 32 & 32 & 53 & 63 & 21 & 30 \\
\hline St. Sapma & & & 1,40 & 1,78 & 2,39 & 3,61 & 1,24 & 1,48 \\
\hline
\end{tabular}

iBY: İlk bakla yüksekliği

B.B.: Bitki boyu

O.G.S.:Olgunlașma gün sayısı

Çizelge 2. Sera Koșullarında Elde Edilen Gözlem Değerleri

Table 2. Observation values in greenhouse conditions

\begin{tabular}{|c|c|c|c|c|c|c|c|c|}
\hline \multirow[b]{2}{*}{ Hat/Çeșit } & \multirow{2}{*}{$\begin{array}{l}\text { Ekim } \\
\text { Tarihi }\end{array}$} & \multirow{2}{*}{$\begin{array}{l}\text { Çıkıș } \\
\text { Tarihi }\end{array}$} & $50 \%$ & İBY & B.B. & O.G.S. & Bakla & Bitkide \\
\hline & & & $\begin{array}{l}\text { Ç.G.S. } \\
\text { (gün) }\end{array}$ & $(\mathrm{cm})$ & $(\mathrm{cm})$ & (gün) & $\begin{array}{l}\text { Sayısı } \\
\text { adet }\end{array}$ & $\begin{array}{l}\text { Tohum } \\
\text { Sayısı adet }\end{array}$ \\
\hline $\mathrm{F} 1-1$ & 21. Haz & 24. Haz & 55 & 24 & 44 & 85 & 18 & 25 \\
\hline $\mathrm{F} 1-1$ & 21. Haz & 24. $\mathrm{Haz}$ & 50 & 24 & 47 & 80 & 17 & 24 \\
\hline $\mathrm{F} 1.1$ & 21. Haz & 23. Haz & 55 & 23 & 45 & 85 & 19 & 27 \\
\hline F1-2 & 21. Haz & 24. Haz & 54 & 25 & 47 & 84 & 18 & 27 \\
\hline $\mathrm{F} 1-2$ & 21. Haz & 23. Haz & 52 & 27 & 49 & 82 & 19 & 24 \\
\hline F1-2 & 21. Haz & 23. Haz & 56 & 24 & 50 & 86 & 17 & 24 \\
\hline F1-3 & 21. Haz & 24. Haz & 60 & 28 & 48 & 90 & 20 & 28 \\
\hline F1-3 & 21. Haz & 23. Haz & 58 & 27 & 47 & 89 & 17 & 27 \\
\hline F1-3 & 21. Haz & 24. Haz & 57 & 29 & 44 & 87 & 16 & 26 \\
\hline Çiftçi & 21. Haz & 23. Haz & 57 & 28 & 48 & 89 & 14 & 24 \\
\hline Çiftçi & 21. Haz & 24. Haz & 59 & 29 & 45 & 90 & 18 & 28 \\
\hline Çiftçi & 21. Haz & 24. Haz & 60 & 27 & 49 & 94 & 18 & 28 \\
\hline Minimum & & & 50 & 24 & 44 & 80 & 14 & 24 \\
\hline Maksimum & & & 60 & 29 & 50 & 94 & 20 & 28 \\
\hline Ortalama & & & 56 & 26 & 47 & 87 & 17 & 26 \\
\hline St. Sapma & & & 3,09 & 2,14 & 2,20 & 3,89 & 1,56 & 1,71 \\
\hline
\end{tabular}

iBY: İlk bakla yüksekliği

B.B.: Bitki boyu

O.G.S.: Olgunlașma gün sayısı 
Çizelge 3. Iklim Odası ve Sera Koșullarında Alınan Gözlem Değerlerinin Karșılaștırılması

Table 3. Compare with observation values in controlled growth room and greenhouse conditions

\begin{tabular}{|c|c|c|c|c|c|c|c|c|}
\hline \multirow[b]{2}{*}{ Hat/Çeșit } & \multirow{2}{*}{$\begin{array}{l}\text { Ekim } \\
\text { Tarihi }\end{array}$} & \multirow{2}{*}{$\begin{array}{l}\text { Çıkış } \\
\text { Tarihi }\end{array}$} & $\% 50$ & İBY & B.B. & O.G.S. & Bakla & Bitkide \\
\hline & & & Ç.G.S. (gün) & $(\mathrm{cm})$ & $(\mathrm{cm})$ & (gün) & $\begin{array}{l}\text { Sayısı } \\
\text { adet }\end{array}$ & $\begin{array}{c}\text { Tohum } \\
\text { Sayısı adet }\end{array}$ \\
\hline \multicolumn{9}{|c|}{ İklim Odası } \\
\hline $\mathrm{F} 1-1$ & 21. Haz & 22. Haz & 30 & 30 & 50 & 60 & 20 & 30 \\
\hline $\mathrm{F} 1-1$ & 21.Haz & 23. Haz & 32 & 30 & 57 & 62 & 21 & 31 \\
\hline $\mathrm{F} 1.1$ & 21. Haz & 22. Haz & 32 & 30 & 55 & 64 & 22 & 30 \\
\hline $\mathrm{F} 1-2$ & 21. Haz & 22. Haz & 34 & 34 & 55 & 64 & 20 & 29 \\
\hline F1-2 & 21.Haz & 22.Haz & 32 & 32 & 53 & 65 & 22 & 28 \\
\hline $\mathrm{F} 1-2$ & 21. Haz & 23. Haz & 34 & 35 & 54 & 64 & 24 & 28 \\
\hline $\mathrm{F} 1-3$ & 21. Haz & 22. Haz & 33 & 31 & 50 & 67 & 20 & 30 \\
\hline F1-3 & 21.Haz & 23. Haz & 30 & 33 & 52 & 65 & 21 & 28 \\
\hline $\mathrm{F} 1-3$ & 21. Haz & 22. Haz & 32 & 34 & 53 & 68 & 20 & 32 \\
\hline Çiftçi & 21. Haz & 22. Haz & 30 & 32 & 50 & 60 & 22 & 30 \\
\hline Çiftçi & 21. Haz & 22.Haz & 32 & 34 & 50 & 60 & 21 & 27 \\
\hline Çiftçi & 21. Haz & 22. Haz & 31 & 33 & 51 & 55 & 20 & 28 \\
\hline \multicolumn{9}{|c|}{ Sera } \\
\hline F1-1 & 21.Haz & 24.Haz & 55 & 24 & 44 & 85 & 18 & 25 \\
\hline $\mathrm{F} 1-1$ & 21.Haz & 24. Haz & 50 & 24 & 47 & 80 & 17 & 24 \\
\hline F1.1 & 21. Haz & 23. Haz & 55 & 23 & 45 & 85 & 19 & 27 \\
\hline $\mathrm{F} 1-2$ & 21.Haz & 24.Haz & 54 & 25 & 47 & 84 & 18 & 27 \\
\hline $\mathrm{F} 1-2$ & 21.Haz & 23. Haz & 52 & 27 & 49 & 82 & 19 & 24 \\
\hline F1-2 & 21.Haz & 23. Haz & 56 & 24 & 50 & 86 & 17 & 24 \\
\hline F1-3 & 21.Haz & 24. Haz & 60 & 28 & 48 & 90 & 20 & 28 \\
\hline F1-3 & 21. Haz & 23. Haz & 58 & 27 & 47 & 89 & 17 & 27 \\
\hline F1-3 & 21. Haz & 24.Haz & 57 & 29 & 44 & 87 & 16 & 26 \\
\hline Çiftçi & 21.Haz & 23. Haz & 57 & 28 & 48 & 89 & 14 & 24 \\
\hline Çiftçi & 21. Haz & 24. Haz & 59 & 29 & 45 & 90 & 18 & 28 \\
\hline Çiftçi & 21. Haz & 24. Haz & 60 & 27 & 49 & 94 & 18 & 28 \\
\hline Minimum & & & 44 & 23 & 44 & 55 & 14 & 24 \\
\hline Maksimum & & & 60 & 35 & 57 & 94 & 24 & 32 \\
\hline Ortalama & & & 44 & 29 & 50 & 75 & 19 & 28 \\
\hline St. Sapma & & & 12,61 & 3,65 & 3,58 & 12,75 & 2,25 & 2,28 \\
\hline
\end{tabular}

\section{Bitkilerin Çıkıș Tarihi}

İklim odası ve sera koşullarında bitkilerin çıkış süresine ilişkin analiz sonuçları Çizelge 1 ve Çizelge 2'de verilmiștir. İklim odasındaki (hızlı ıslah) bitkilerin 1-2 gün içerisinde seradaki (kontrol) bitkilerin ise 3-4 gün içerisinde \% 90'ının çıkış yaptığı gözlenmiştir.

\section{\%50 Çiçeklenme Gün Sayısı}

Çizelge 1 ve Çizelge 2'de görüldüğü üzere iklim odasında uzun fotoperiyota maruz kalan bitkilerde (hızlı ıslah) çiçeklenme gün sayısı ortalama 32 gün, serada normal fotoperiyot koșullarında (kontrol) ortalama 56 gün içersinde çiçeklenme gözlenmiștir. Ghosh ve ark. (2018) yapmıș oldukları çalıșmada nohutta sera koșullarında çiçeklenme gün sayısının 60 gün, iklim odası koșullarında ise çiçeklenme gün sayısının 35 gün civarında olduğunu belirlemiștir. Öte yandan düşük ışık yoğunluğunda yetiştirilen bitkilere göre yüksek ışıklanma süresi ve ışık yoğunluğunda yetiștirilen bitkilerde çiçeklenme gün sayısı ve 
generasyon süresinin kısaldığı belirtilmektedir (Smedley ve ark. 2015).

\section{Bitki Boyu}

Çizelge 1 ve Çizelge 2'de sunulduğu üzere iklim odasında uzun süre ıșık yoğunluğuna maruz bırakılan bitkilerde bitki boyu ortalaması $53 \mathrm{~cm}$, serada normal fotoperiyot koșullarında bitki boyu ortalaması $47 \mathrm{~cm}$ olarak ölçülmüștür (Șekil 4.) Ghosh ve ark. (2018) yilında yapmış oldukları çalışmada, ışıklanma süresi ve ışık yoğunluğunun arttıkça bitki boyunda artı̧̧ar gözlediklerini belirtmiștir (Smedley ve ark., 2015).

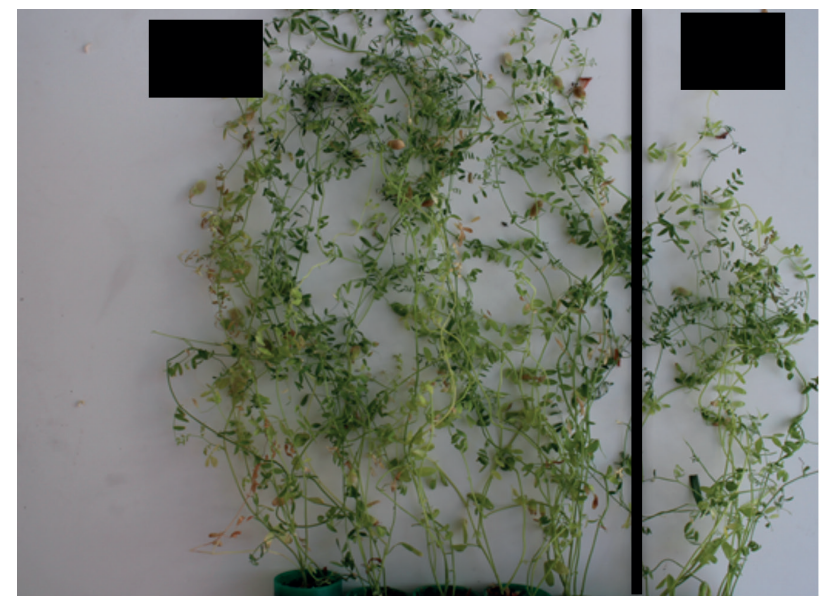

a)

\section{Ilk Bakla Yüksekliği}

Çizelge 1 ve Çizelge 2'de görüldüğü üzere iklim odasında uzun süre ıșık yoğunluğuna maruz bırakılan bitkilerde iklim odasında ilk bakla yüksekliği ortalama $32 \mathrm{~cm}$, normal koșullarda serada yetișen bitkilerde ortalama $26 \mathrm{~cm}$ olarak ölçülmüștür.

\section{Olgunlașma Gün Sayısı}

Çizelge 1 ve Çizelge 2'de belirtildiği üzere iklim odasında uzun süre ıșık yoğunluğuna maruz bırakılan iklim odasındaki bitkilerde çiçeklenmeden 3 hafta sonra baklalar tam olgunlașmadan ortalama 63 gün sonra hasat edilmiștir (Șekil 5). Normal ıșık yoğunluğunda

Șekil 4. a) İklim odası (hızlı ıslah) koșullarında F1-3 populasyonu bitki boyu $(52,5 \mathrm{~cm})$

b) Sera (Kontrol) koșullarında F1-3 populasyonu bitki boyu $(45 \mathrm{~cm})$

Figure 4 a) F1-3 population plant height under controlled growth room (speed breeding) conditions

b) Plant height of F1-3 population under greenhouse (control) conditions

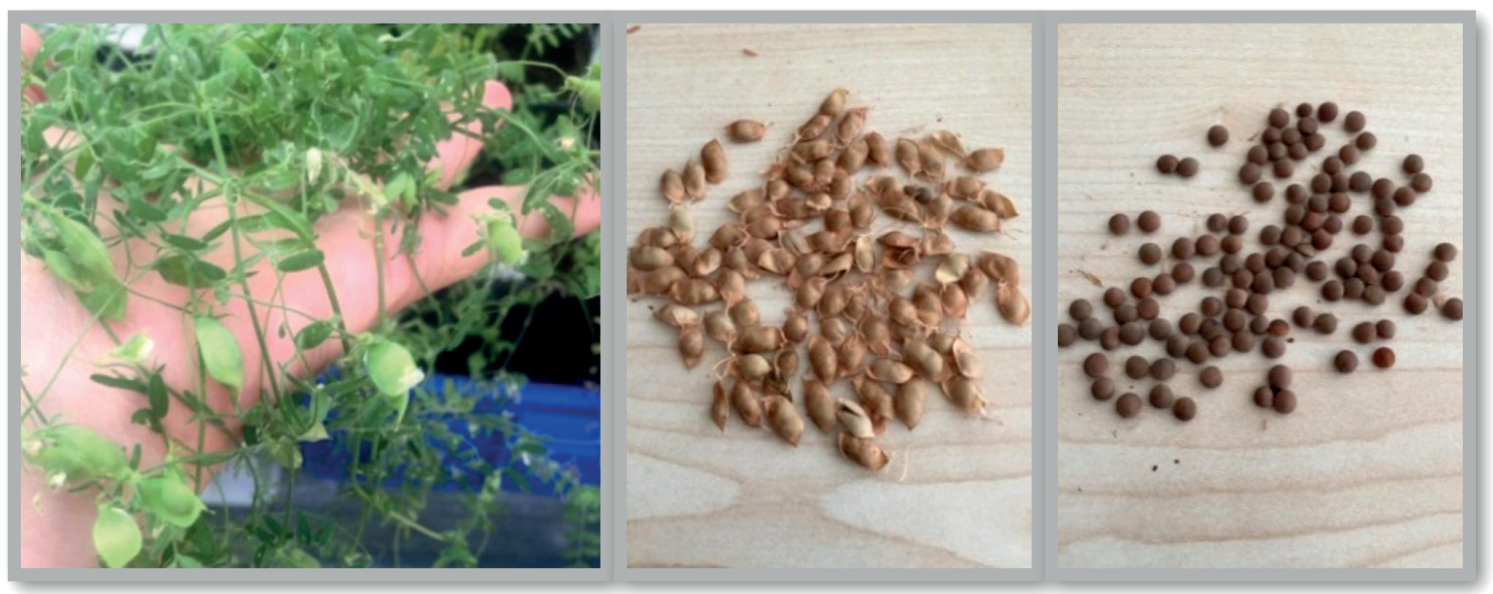

Șekil 5. 60 gün içerisinde 1 generasyon ilerletilen $\mathrm{F} 1-1$ populasyonu

Figure 5. F1 population which was improved 1 generation within 60 days 
yetișen seradaki bitkiler ise tohumlar çiçeklenmeden 4-5 hafta sonra baklalar tam olgunlașmadan ortalama 87 günde hasat edilmiștir. Ghosh ve ark. (2018) çalışmasında olduğu gibi hasat olgunluğunu hızlandırmak için bitkiler hasat edilmeden önceki hafta hiç sulanmamıștır.

\section{Bitkide Bakla Sayısı}

Çizelge 1 ve Çizelge 2'de belirtildiği üzere iklim odasında uzun süre ıșık yoğunluğuna maruz bırakılan iklim odasındaki bitkilerde bakla sayısı iklim odasında ortalama 21 adet, normal ıșık yoğunluğunda kontrol serada bakla sayısı ortalama 17 adet olarak hesaplanmıștır.

\section{Bitkide Tohum Sayısı}

Çizelge 1 ve Çizelge 2'de belirtildiği üzere iklim odasında uzun süre ıșık yoğunluğuna maruz bırakılan iklim odasındaki bitkilerde tohum sayısı iklim odasında ortalama 30 adet, serada ortalama 26 adet olarak tespit edilmiștir.

\section{Sonuç}

Birçok ürün grubunda yeni bir çeşit geliştirmek uzun yıllar almaktadır. Baklagillerde melezleme sonrası genetik olarak durulmuș hatlar geliștirmek için ortalama olarak 6-7 nesil geçmesi gerekmektedir. Arazi koșullarında yürütülen klasik mercimek ıslah çalıșmalarını hızlandırmak ve daha kısa sürede generasyon ilerletmek için bu çalışmaya intiyaç duyulmuştur. Sonuç olarak, bu çalıșma ile herbisite dayanıklılık yönünden yapılan melezleme çalıșmaları neticesinde elde edilen F1 populasyonlarında hızı bitki ıslahı teknikleri kullanılarak kısa sürede 1 generasyon ilerletme sağlanmıștır.

Bazı bitkilerin tohumları çimlenme için ıșık etkisine intiyaç duymakta, bazıları ise karanlık ortamda çimlenmektedir. Sera ve iklim odasında alınan gözlemler dikkate alındığında bitkilerin çıkıș tarihleri arasında çok fazla fark ortaya çıkmamıștır. Çalışmada tohumlara giberellik asit ve soğuk ön uygulamasıyla tohumların çıkıș süresi kısalmıș ve bitkilerde homojen çıkıș sağlanmıștır (Çizelge 3).

Yüksek ıșıklanma koșullarında yetiștirilen bitkilerde, az ıșı yoğunluğunda yetiștirilenlere kıyasla farklı morfolojik ve fizyolojik özellikler ortaya çıkmaktadır. İklim odasında uzun fotoperiyota maruz kalan bitkilerin, sera da normal fotoperiyotta yetiștirilenlere göre \% 50 çiçeklenme gün sayısı ortalamasının daha kısa olduğu tespit edilmiștir. Ghosh ve ark. (2018) yapmıș oldukları çalıșmada yüksek ışıklanma koşullarında yetișen bitkilerde erken çiçeklenmegözledikleriniifadeetmiștir. Çalışma sonucunda uzun gün bitkisi olan mercimek daha uzun günlük ıșıklanma koșullarında (örn; 22 saat ıșık) yetiștirildiğinde, olgunlașma süresinin kısalmıștır. Işıklanma süresi arttıkça mercimeğin vejetatif gelişmesinde gerileme, generatif gelișme devrelerinde (çiçeklenme, tohum bağlama) hızlanma gözlenmiştir.

Bu çalıșmada bitkilerin hem günlük ıșığa maruz kalma süresinin uzatılması hem de erken tohum hasadı gerçekleștirilmesi suretiyle populasyonlar 60 gün içerisinde 1 generasyon ilerletilmiștir. Mercimekte hızlı ıslah teknikleri ile ilgili șuanda yapılmıș bir çalıșma olmamakla birlikte çalıșma ile hızlı ıslah (speed breeding) koșulları optimize edilmiștir. Sonuç olarak, bu teknik sayesinde kısa sürede istenilen özellikte mercimek çeșitleri geliștirilecektir.

Aynı zamanda bu çalıșmanın bașka bitki türlerinde yapılacak çalıșmalara model olușturacağı ve klasik ıslah çalıșmalarına entegre edileceği öngörülmektedir.

\section{Kaynaklar}

Ball, D.A., Ogg, A.G., \& Chevalier, P. M. (1997). The influence of seeding rate on weed control in small-red lentil (Lens culinaris). Weed Science, 45(2), 296-300.

Bukun, B., \& Guler, B. H. (2005). Densities and importance values of weeds in lentil production. Int. J. Bot, 1(1), 15-18.

Croser, J. S. (2002). Haploid and zygotic embryogenesis in chickpea (Cicer arietinum L.). $\mathrm{PhD}$, The University of Melbourne, Melbourne, Australia.

Cubero, J. I. (1984). Taxonomy, distribution and evolution of the lentil and its wild relatives. In Genetic Resources and Their ExploitationChickpeas, Faba beans and Lentils (pp. 187203). Springer.

Ghosh, S., Watson, A., Gonzalez-Navarro, O. E., Ramirez-Gonzalez, R. H., Yanes, L., MendozaSuárez, M., ... Green, P. (2018). Speed breeding in growth chambers and glasshouses for crop breeding and model plant research. Nature Protocols, 13(12), 2944. 
Grewal, R. K., Lulsdorf, M., Croser, J., Ochatt, S., Vandenberg, A., \& Warkentin, T. D. (2009). Doubled-haploid production in chickpea (Cicer arietinum L.): role of stress treatments. Plant Cell Reports, 28(8), 1289-1299.

Halila, M. H. (1994). Status and potential of wintersowing of lentil in Tunisia. In Proceedings of the workshop on towards improved winter-sown lentil production for the West Asia and North African highlands (pp. 172-183).

Köse, Ö. D. E., Bozoğlu, H., \& Zeki, M. U. T. (2017). Yozgat Koșullarında Yetiștirilen Yeșil Mercimek Genotiplerinin Verimine Ekim Sıklı̆ı̆ın Etkisi. KSÜ Doğa Bilimleri Dergisi, 20, 351-355.

Panchangam, S. S., Mallikarjuna, N., Gaur, P. M., \& Suravajhala, P. (2014). Androgenesis in chickpea: Anther culture and expressed sequence tags derived annotation.

Ray, D. K., Mueller, N. D., West, P. C., \& Foley, J. A. (2013). Yield trends are insufficient to double global crop production by 2050. PloS One, 8(6), e66428.

Singh, K. B., Malhotra, R. S., \& Witcombe, J. R. (1983). Kabuli chickpea germplasm catalog.
Smedley, D., Jacobsen, J. O. B., Jäger, M., Köhler, S., Holtgrewe, M., Schubach, M., Washington, N. L. (2015). Next-generation diagnostics and disease-gene discovery with the Exomiser. Nature Protocols, 10(12), 2004.

Tan, S., Evans, R. R., Dahmer, M. L., Singh, B. K., \& Shaner, D. L. (2005). Imidazolinone?tolerant crops: history, current status and future. Pest Management Science: Formerly Pesticide Science, 61(3), 246-257.

Thonke, K. E. (1991). Political and practical approaches in Scandinavia to reduce herbicide inputs. In Brighton Crop Protection ConferenceWeeds.

Tuik 2018, A. (n.d.). Bitkisel üretim istatistikleri kuru baklagiller değerlendirme raporu.

Zulkadir, G., Çölkesen, M., İdikut, L., Çokkizgin, A., Girgel, Ü., Tanrikulu, A., Güneş, M. (2015). Kahramanmaraș Koșullarında Farklı Mercimek (Lens culinaris Medic.) Genotiplerinde Bitki Sıklığının Verim ve Verim Unsurlarına Etkisinin Araștırması. Harran Tarım ve Gıda Bilimleri Dergisi, 19(3), 135-143. 